\author{
Ryszard Skowron
}

(Kraków/Katowice)

https://orcid.org/0000-0001-9131-2832

\title{
BUDOWANIE PRESTIŻU KRÓLEWSKIEGO RODU. ZWIĄZKI RODZINNE WAZÓW Z DYNASTIAMI EUROPEJSKIMI
}

\begin{abstract}
Marriages enabled the House of Vasa to enter into the network of courts throughout Europe and opened a way to participate in the processes of assimilation, reception or rejection of respective cultural, religious, and political paradigms. The bonds of kinship became one of the most effective instruments to raise the prestige and the standing of dynasty, which sought to occupy an ever higher position in the hierarchy of European rulers. The aim of this paper is to show how the House of Vasa functioned within he contemporaneous dynastic networks in Europe on the examples of several selected issues of strictly familial nature: inheritance of names, christenings, family reunions and financial security.
\end{abstract}

\section{Keywords}

the Vasa, Habsburgs, dynastic policy, prestige, christenings, travels.

Małżeństwa umożliwiały Wazom wejście w sieć dworów rozrzuconych po całej Europie i otwierały drogę do uczestniczenia w procesach asymilacji, recepcji lub odrzucenia ich wzorów kulturowych, religijnych i politycznych. Więzy pokrewieństwa stały się jednym z najskuteczniejszych instrumentów podnoszeniu prestiżu i pozycji dynastii, która chciała zajmować coraz wyższe miejsce w hierarchii prestiżu władców Europy. Małżeństwa miały stać się podstawą stabilizacji dynastii oraz bazą do stworzenia i ugruntowania mitu własnego rodu. Interakcje dynastyczne tworzą złożony system powiązań rodzinnych, politycznych i kulturowych. Celem niniejszego tekstu jest ukazanie sposobu funkcjonowania Wazów w sieciach dynastycznych ówczesnej Europy na przykładzie kliku wybranych zagadnień o charakterze ściśle rodzinnym czy wręcz osobistym. 


\section{EUROPEJSKA SIEĆ ZWIĄZKÓW RODZINNYCH}

Dom Wazów. Relacje Wazów szwedzkich z innymi rodami europejskimi były bardzo ograniczone, dynastia była młoda a krąg rodzinny Zygmunta III w momencie objęcia tronu Rzeczpospolitej wiązał się przede wszystkim z braćmi i siostrami jego ojca ${ }^{1}$. Potomek Jagiellonów miał tylko siostrę Annę, która u jego boku przebywała na dworze polskim, a brat przyrodni Jan, z małżeństwa jego ojca z Gunillą Bielke, urodzi się dopiero w roku 1589. Dla założyciela dynastii Gustawa I utrzymanie władzy i wzmocnienie niezależności Szwecji oraz budowania prestiżu rodu stanowiły najważniejsze cele. Nie było to łatwe, pozbawił on bowiem tronu w Sztokholmie Chrystiana II, szwagra cesarza, i uważany był na dworach Europy za uzurpatora. Gustaw wiedział, że pozycję rodu może podnieść przede wszystkim poprzez koligacje z królewskimi dynastiami Europy. Niepowodzeniem zakończyły się poszukiwania dla siebie i pierworodnego syna Eryka kandydatek na żony na największych dworach leżących między Londynem a Krakowem. Ostatecznie Gustaw musiał zadowolić się małżeństwem z Katarzyną, córką Magnusa, księcia saskiego na Lauenburgu, wywodzącego się z starej dynastii askańskiej i skoligaconego z Hohenzollernami i książętami Pomorza. Drugie małżeństwo król zawarł już ze Szwedką Małgorzatą Leijonhufvud, która urodziła mu dziesięcioro dzieci. Daremne okazało się również zabieganie Eryka XIV o rękę księżniczki z rodu królewskiego i ostatecznie poślubił on swoją kochankę Karin Månsdotter.

Przestrzeń geograficzna dworów europejskich, na których znajdowali się krewni Zygmunta III, była stosunkowo ograniczona, ponieważ obejmowała jedynie terytorium Rzeszy. Wyjątkiem był ślub jego ojca księcia Jana z Katarzyną Jagiellonką, córką króla Polski. Wydarzenie to miało olbrzymie znaczenia dla dziejów rodu, bo syn zrodzony z tego małżeństwa sięgnie po koronę polską i stanie się założycielem polskiej linii rodu. Zawężenie do książąt niemieckich i własnych poddanek więzów powinowactwa i pokrewieństwa szwedzkich Wazów spowodowane było kilkoma przyczynami: dynastycznymi - niewielki prestiż rodu, religijnymi - dwory protestanckie, i politycznymi - potencjalni sojusznicy w konflikcie z Danią i Moskwą. Król Jan III, ojciec Zygmunta, miał pięć sióstr: Katarzynę, Cecylię, Annę, Zofię i Elżbietę, i dwóch braci rodzonych: Magnusa i Karola, i starszego brata przyrodniego Eryka XIV. Kiedy młody Waza został wybrany na króla państwa polsko-litewskiego, wszystkie jego stryjne i stryj Karol byli w związkach małżeńskich i posiadali dzieci. Tylko Magnus, książę Östergötlandu, do końca życia pozostał kawalerem. W 1588 roku Zygmunt III miał 27 żyjących sióstr i braci stryjecznych,

${ }^{1}$ Koligacje rodzinne szwedzkich Wazów opracowano na podstawie „Svenskt biografiskt lexikon" dostępnego [online] (Riksarkivet w Sztokholmie) oraz prac: Larsson 2005 i 2009, Wolke 2011, Petersson 2015 i Kopczyński 2002. 
a do tego należy jeszcze dodać czwórkę dzieci stryja Karola i Krystyny Holsztyńskiej, które urodzą się po zawarciu przez nich małżeństwa w roku 1592. Po stronie Katarzyny, matki króla, żyła jedynie Anna Jagiellonka, królowa-wdowa.

Zygmunt III i jego potomkowie poprzez małżeństwa sióstr Jana III stali się częścią wazowskiej sieci rodzinno-dworskiej na terenie Rzeszy obejmującej: Fryzję Wschodnią (Katarzyna i jej dzieci z małżeństwa z hrabią Edzardem II), Badenię-Rodemachern (Cecylia i jej dzieci z małżeństwa z margrabią Krzysztofem II), Palatynat-Veldenz (Anna i jej dzieci z małżeństwa z palatynem Janem Jerzym), Saksonię-Lauenburg (Zofia i jej syn z małżeństwa z księciem Magnusem II ) i Meklemburgię-Gadebusch (Elżbieta i jej córka z małżeństwa z księciem Krzysztofem). Osobną grupę stanowili krewni, którzy żyli w Szwecji. Z dzieci stryja Karola należy wymienić przede wszystkim córkę Katarzynę, która poślubiła palatyna Zweibrücken i była matką późniejszego króla Karola X Gustawa, oraz syna Gustawa Adolfa i córką Marię Elżbietę ze związku z księżną Krystyną Holsztyńską. Zmarły w 1577 r. stryj Eryk XIV pozostawił syna Gustawa Erriksona² i córkę Sygrydę, którzy przez jakiś czas przebywali na dworze Zygmunta III.

Dom Austrii. Zygmunt III, mimo że został wyniesiony na tron Rzeczypospolitej przez stronnictwo antyhabsburskie i musiał walczyć o koronę z arcyksięciem Maksymilianem, od początku swych rządów dążył do zbliżenia z Domem Austrii. Król zdawał sobie sprawę, że trwały konflikt z cesarzem i członkami jego rodziny oraz nie najlepszy stosunki z Francją grożą mu izolacją na arenie międzynarodowej. Wszystkie okoliczności wskazywały na konieczność sojuszu z Habsburgami³, jedynym potencjalnym sprzymierzeńcem w tej części Europy, który nie tylko mógł udzielić Rzeczypospolitej wsparcia w konfliktach z Turcją i Moskwą, ale również dostarczyć wzorów ideowych i kulturowych, tak potrzebnych młodemu władcy i jego rodzinie. Podstawowym narzędziem w realizacji polityki współpracy i sojuszu z Habsburgami były dla Wazów małżeństwa. W realiach ustrojowych i politycznych Rzeczypospolitej związki małżeńskie ważne były nie tylko z powodów politycznych, ale przede wszystkich prestiżowych, bo zapewniały stabilizację dynastii i jej wysoką pozycję wśród europejskich dworów. Żony Habsburżanki miały być podstawą do włączenia się Wazów w europejską sieć dworów i zbudowania kanałów wymiany kulturowej i współpracy politycznej.

Obie żony Zygmunta III, Anna i Konstancja, były córkami arcyksięcia Karola II, władcy Austrii Wewnętrznej (Styria, Karyntia i Karniola) i Marii Anny Wittelsbach,

2 Boras 1985, passim.

${ }^{3}$ O procesie normalizacji relacji Zygmunta III z Habsburgami w latach 1588-1592 zob. Barwicka 2019. 
córki księcia Bawarii Albrechta $\mathrm{V}^{4}$. W żyłach ich ojca płynęła krew jagiellońska, gdyż był on najmłodszym synem cesarza Ferdynanda I i Anny Jagiellonki. Stryjami obu królowych polskich byli cesarz Maksymilian II, żonaty z Marią Hiszpańską, arcyksiążę Ferdynand II, władca Tyrolu, którego pierwsza, morganatyczna żona pochodziła z patrycjuszowskiego rodu Welserów, druga zaś, Anna Katarzyna z Gonzagów, książąt Mantui. Spośród kilkunastu sióstr ich ojca wymienić należy te, które rozbudowywały lub utrwalały sieć koligacji rodzinnych: Elżbietę i Katarzynę, żony Zygmunta Augusta króla Polski, Annę małżonkę Albrechta V, księcia Bawarii, Eleonorę, która poślubiła Wilhelma I Gonzagę, księcia Mantui i Monfferato, oraz Joannę, żonę Franciszka I Medyceusza, wielkiego księcia Toskanii. Jednak w momencie zawierania ślubu przez arcyksiężniczkę Annę z Zygmuntem III w 1592 r. spośród tych krewnych żyła tylko ciotka Eleonora. Więcej żyjących wujów miały obie Austriaczki po stronie matki: księcia Bawarii Wilhelma V Wittelsbacha i jego młodszych braci, Ferdynanda i Ernsta, oraz ciotkę Maksymilianę Marię. Braćmi stryjecznymi królowych byli kolejni cesarze Rudolf II i Maciej oraz arcyksiążęta: Ernest, Maksymilian i Albert VII, gubernator Niderlandów Południowych.

Poprzez małżeństwa z Anną i Konstancją Zygmunt III spowinowacił się z Habsburgami, ale członkami tego rodu po kądzieli stały się ich dzieci. Karol II Styryjski i Maria Bawarska mieli piętnaścioro dzieci, i chociaż kilkoro z nich zmarło w niemowlęctwie lub dzieciństwie, to bracia i siostry obu żon tworzyły liczącą jedenaście osób grupę wujów i ciotek po kądzieli dla urodzonych z obu małżeństw dzieci króla polskiego. Dla królewicza Władysława i jego przyrodnich braci wujami byli: cesarz Ferdynand II, arcyksiążęta: Maksymilian Ernest, mistrz zakonu krzyżackiego, Leopold V, władca Austrii Przedniej i Tyrolu oraz Karol, biskup Wrocławia i Brixen, a ciotkami m.in. arcyksiężniczki: Maria Krystyna, żona Zygmunta Batorego, księcia Siedmiogrodu, Małgorzata, która poślubiła Filipa III króla Hiszpanii, oraz Maria Magdalena, małżonka Kosmy II Medyceusza, księcia Toskanii. Dzieci urodzone ze związków wujów i ciotek tworzyły sieć ponad dwudziestu kuzynów i kuzynek (braci i sióstr ciotecznych i wujecznych) rozsianych po całej Europie. Wśród nich byli m.in. cesarz Ferdynand III, którego żonami były: Maria Anna córka Filipa III, arcyksiężniczka Maria Leopoldyna Tyrolska, córka arcyksięcia tyrolskiego Leopolda V, i Eleonora Gonzaga, córka Karola II, księcia Mantui, Filip IV, król Hiszpanii, Anna Maria, żona króla Francji Ludwika XIII, infant-kardynał Ferdynand, gubernatora Niderlandów, arcyksiążę Ferdynand Karol Tyrolski, arcyksiężniczka Izabela Klara, żona Karo-

${ }^{4}$ Koligacje rodzinne Anny i Konstancji, królowych polskich z Domu Habsburgów oraz ich potomstwa opracowano na podstawie Leitsch 2009, I-IV, Dworzaczek 1959, Erbe 2000. 
la III, księcia Mantui, Ferdynand II Medyceusz, wielki książę Toskanii. Związki dynastyczne jeszcze bardziej się poszerzyły i zaczęły się krzyżować, kiedy w roku 1637 król Władysław IV poślubił Cecylię Renatę, córkę swojego wuja cesarza Ferdynanda II.

Dom Hohenzollernów. Najstarszą ciotką Zygmunta III z dynastii Jagiellonów była Jadwiga, córka Zygmunta I i Barbary Zápolyi, która w 1535 r. wyszła za mąż za margrabiego Brandenburgii Joachima II. Z małżeństwa Jagiellonki z elektorem przyszło na świat sześcioro dzieci. W momencie obejmowania tronu przez Wazę w Rzeczypospolitej ciotka ta nie żyła już od ponad czternastu lat, a z sześciorga dzieci Jadwigi i Joachima II żyły tylko dwie siostry cioteczne króla: bezdzietna Elżbieta Magdalena i Jadwiga, żona Juliusza, księcia brunszwickiego na Wolfenbüttel z dynastii Welfów.

Dom Medyceuszy. Małżeństwa zawierane przez Habsburgów z wielkimi książętami Toskanii sprawiły, że koligacje rodzinne dzieci Zygmunta III objęły po kądzieli ród Medyceuszy. Maria Magdalena Austriaczka, ciotka Władysława IV i jego przyrodnich braci, w 1608 wyszła za mąż za Kosmę II, z którym miała ośmioro dzieci. Kuzynami Wazów byli m.in. Ferdynand II, wielki książę Toskanii, Małgorzata, żona księcia Parmy Odoarda Farnese, oraz kardynałowie Gian Carlo i Leopoldo de' Medici.

Dom Gonzagów. Władysław IV i Jan Kazimierz, zawierając związek małżeński z Ludwiką Marią, weszli w związki powinowactwa z rodem Gonzagów de Nevers, którzy w następstwie wojny sukcesyjnej w 1631 objęli władzę w księstwie Mantui. Zdaniem Urszuli Augustyniak księżniczka de Nevers „niezależnie od osobistych zdolności - z pewnością nie była "partią» odpowiednią dla polskiego króla ani z racji wieku (35 lat), ani koligacji czy posagu"5. Władysław IV wymusił na królu francuskim wprowadzenie do intercyzy ślubnej zapisu podnoszącego Ludwikę Marię do rangi księżniczki krwi. Jak wykazał Tadeusz Szulc, niespełnienie przez Ludwiku XIV tego żądania króla polskiego „groziło następstwami wynikającymi z morganatycznego związku małżeńskiego"6. Urodzona ze związku z królem Janem Kazimierzem córka Maria Anna Teresa zmarła po roku, zaś syn Jan Zygmunt żył tylko półtora miesiąca. Kiedy Ludwika Maria w 1646 r. przybyła do Polski, nie żyli jej rodzice, a z piątki rodzeństwa pozostała jedynie najmłodsza siostra Anna Maria, która w kwietniu 1645 r. wyszła za mąż za Edwarda, księcia

\footnotetext{
5 Augustyniak 1999, s. 161.

6 Szulc 2015, s. 151, szerzej na ten temat zob. Szulc 2016.
} 
Palatynatu-Simmern. Bratanek królowej Karol III Gonzaga panował w księstwie Mantui. Taka sytuacja rodzinna powodowała, że związki między Wazami o Gonzagami miały bardzo ograniczony zasięg.

Dom Wittelsbachów. Poprzez związki małżeńskie Wazowie weszli na terenie Rzeszy w koligacje z Wittelsbachami. W pierwszej kolejności była to Maria Bawarska, teściowa Zygmunta III i babka jego dzieci z małżeństw z obu Habsburżankami. I chociaż pokrewieństwo było dość odległe, Zygmunt III chętnie podkreślał związki z tym rodem, m.in. zapraszając jego przedstawicieli na rodziców chrzestnych swoich dzieci, a szczególna manifestacja związków rodzinnych miała miejsce w czasie pobytu w Bawarii królewicza Władysława. Koligacje rodzinne zacieśniły się, kiedy w 1642 r. Władysław IV wydał siostrę Annę Katarzynę Konstancję za Filipa Wilhelm Wittelsbacha, księcia Neuburga, który był synem Magdaleny, bratanicy Marii Bawarskiej. Poprzez to małżeństwo Wazówna stała się „ogniwem scalającym cztery wielkie rody Europy: dynastię Habsburgów i Wittelsbachów z jednej strony oraz Jagiellonów i Wazów z drugiej"7. Para nie miała jednak dziecka, a Wazówna zmarła nagle w 1652 r. Po abdykacji Jana Kazimierza Filip Wilhelm był jednym z kandydatów do korony polskiej.

\section{PRESTIŻ I WZMACNIANIE EUROPEJSKICH WIĘZÓW RODZINNYCH - IMIONA I CHRZTY}

Imię potomka królewskiego i sama uroczystość chrztu miały rozbudowane symboliczne znaczenia. Nie tylko stanowiły moment manifestacji związków dynastycznych, ale odgrywały też ważną rolę propagandową tak w kraju, jak zagranicą. Zygmunt III narzucił wzorzec wyboru imion i doboru rodziców chrzestnych, który realizowali też jego dwaj następcy. Wyznaczone przez niego normy służyły budowaniu historii dynastii, jej mitów i tradycji, które stawały się podstawą tożsamości rodu, utrzymania i wzmocnienia jego pozycji. Z zasady synowie otrzymywali imiona rodu Jagiellonów (Władysław, Kazimierz, Zygmunt, Aleksander), tak aby stawały się one symbolem ciągłości dynastycznej ${ }^{8}$. Znakomicie ujął to historyk królewski Stanisław Kobierzycki, pisząc o imionach pierworodnego syna Zygmunta III:

Na chrzcie, którego udzielił mu Jerzy kardynał Radziwiłł, otrzymał imiona Władysław Zygmunt. To drugie na pamiątkę dwóch swoich pradziadów Zygmuntów Jagiellonów, królów którzy po wsze czasy pozostaną w pamięci; to pierwsze zaś na pamiątkę Władysława Jagieł-

\footnotetext{
${ }^{7}$ Krasińska-Klaupth, Kozłowska, Menhard 2010, s. 38 oraz Żukowski 2017, s. 233-303.

${ }^{8}$ Ochmann-Staniszewska 2006, s. 205-206
} 
ły, pod którego szczęsnym panowaniem Polska starła na proch straszliwe siły wroga oraz jego syna Władysława, króla Węgier, który zginął, walcząc z Turkami pod Warną. Został zatem w ten sposób opromieniony chwałą i nieśmiertelnością imienia oraz wspaniałością czynów swoich imienników9

Nadając imiona swoim synom, król nawiązywał również do tradycji habsburskiej i wazowskiej, czasami imię czy imiona potomka był również odpowiedzią na aktualną sytuację rodzinną lub polityczną. Nieprzypadkowo urodzony w grudniu 1607 r. drugi syn, który przeżył kilkanaście dni, otrzymał imię Jan Kazimierz. Niewątpliwie stanowiło to odpowiedź Zygmunta III na przeprowadzoną w połowie marca tego roku w Uppsali koronację Karola IX. Nadając królewiczowi imię na cześć swojego ojca Jana III, króla Szwecji wysyłał jasny sygnał o dziedzicznym prawie jego potomków do tronu w Sztokholmie, jednocześnie podkreślił tradycje jagiellońskie, przydając mu drugie imię Kazimierz. Ten zawarty w imionach program ideowy musiał być na tyle ważny i zrozumiały dla współczesnych, że kiedy w czternaście miesięcy po śmierci Jana Kazimierza (I) urodził mu się ponownie syn, powtórzył ten zestaw imion. Podobne zabiegi świadomie kształtowanej więzi z Domem Austrii oraz propagandy dynastycznej skierowanej przede wszystkim do dworów europejskich związane są z imionami królewicza Karola Ferdynanda. Otrzymał on imię po arcyksięciu Karolu II Styryjskim, ojcu Anny Austriaczki, i po jej dziadku cesarzu Ferdynandzie I, którego bratem był cesarz Karol V. Zwrócić należy uwagę, że imiona habsburskie zostały nadane pierwszemu synowi urodzonemu w niecałe siedem miesięcy po zawarciu w 1613 r. przez Zygmunta III traktatu przymierza z cesarzem Maciejem. Kolejny potomek króla Aleksander Karol, który przyszedł na świat w listopadzie 1614 r., łączył tradycję jagiellońską z habsburską.

Analogicznie zasady stosowano wobec córek królewskich. Nadawano im imiona związane z tradycją Jagiellonów, Habsburgów i Wazów. W zasadzie stanowiły one różne kombinacje trzech imion: Anna, Maria i Katarzyna. Pierworodna córka Zygmunta III i otrzymała imiona Anna Maria. Pierwsze z nich nadano na cześć królowej Anny, ostatniej z rodu Jagiellonów, pamiętać jednak należy, że obie żony Zygmunta III miały również dwie babki o imieniu Anna: Jagiellonkę, żonę cesarza Ferdynanda I, i Austriaczkę, żonę Albrechta V, księcia Bawarii, co jeszcze dodatkowo eksponowało więzy rodzinne. Drugie z imion zapewne wiązało się z Marią Bawarską, teściową Zygmunta III. Otrzymały je także córki Władysława IV (Anna Maria Izabela) i Jana Kazimierza (Maria Anna Teresa). Imię Maria pojawiło się w Domu Austrii dopiero po małżeństwie cesarza Maksymiliana z Marią Burgundzką. Związek ten stał się podstawą do zbudowania potęgi Domu Austrii. Zygmunt III w swoich działaniach wprowadzał elementy propagandowe, które miały

\footnotetext{
${ }^{9}$ Kobierzycki 2005, s. 16.
} 
wiązać jego rodzinę również ze świetnym i starożytnym dworem burgundzkim. Druga córka Zygmunta III i Anny urodzona w Szwecji otrzymała imię po swojej babce Katarzynie Jagiellonce. Dwie córki urodzone ze związku króla z Konstancją otrzymały imię po matce. Obaj pierwsi Wazowie utrzymywali szczególnie bliskie i serdeczne związki z rządzącą Południowymi Niderlandami infantką hiszpańską Izabelą Klarą Eugenią i jej mężem arcyksięciem Albertem. Dał temu wyraz Władysław IV, nadając córce jako trzecie imię Izabela.

Okazją do pogłębienia więzi rodzinnych był także chrzty ${ }^{10}$. Wybór rodziców chrzestnych stwarzał znakomitą okazję do podniesienia splendoru dynastii, demonstracji koligacji rodzinnych i związków politycznych. Obrzęd chrztu odgrywał istotną rolę we wzmacnianiu spójności szerszej rodziny, a wybór kumów był obserwowany na innych dworach: np. w latach 1613-1619 na dwór florencki systematycznie napływały listy od Alessandra Cilliego, Domenica Gelsomina i Sebastiana Montelupiego zawierające informacje o chrztach i rodzicach chrzestnych dzieci Zygmunta III $^{11}$. Kumowie stawali się znakiem ukazującym pozycję lub co najmniej aspiracje dynastii wśród panujących władców. Dlatego musieli oni również zajmować odpowiednio wysoką rangę w hierarchii europejskiej. Rodzicami chrzestnymi dzieci Wazów najczęściej zostawali członkowie rodu Habsburgów, zarówno linii cesarskiej, jak i hiszpańskiej, którzy nie przybywali jednak osobiście, lecz wysyłali na uroczystości swoich dyplomatów lub wskazywali odpowiednio dostojnych zastępców przebywających w danym momencie w Rzeczypospolitej. Należy pamiętać, że zaproszenia do rodziców chrzestnych wysyłano, nie znając płci przyszłego dziecka, na dwa-trzy miesiące przed rozwiązaniem. Tak więc płeć potomka nie mogła determinować wyboru kumów przez parę królewską.

Rodzicami chrzestnymi pierwszej córki Zygmunta III Anny Marii byli cesarz Rudolf II, Anna Jagiellonka oraz Maria Bawarska. W zastępstwie cesarza przybył do Polski marszałek czeski Wacław Berka z Duba a teściową króla reprezentował Sigismund Thurn von Valsassina ${ }^{12}$. Na ojca chrzestnego Katarzyny, drugiego dziecka, zaproszono księcia Bawarii Wilhelma V, wuja królowej Anny, którego podczas udzielania sakramentu w Sztokholmie zastępował podkanclerzy koronny Jan Tarnowski. Urodzony w 1595 r. Władysław, pierworodny syn Anny i Zygmunta, za rodziców chrzestnych miał arcyksięcia Ferdynanda, brata królowej, i Annę Katarzynę Mantuańską, wdowę po arcyksięciu Ferdynandzie Tyrolskim, oraz Annę Jagiellonkę.

10 Najwięcej informacji dotyczących chrztów Wazów podaje Leitsch 2009, III, s. 1606-1819 oraz IV, s. 2605-2610, zob. też Ochmann-Staniszewska 2006, s. 206-212, Wdowiszewski 205, s. $222-241$.

11 Meysztowicz, Wyhowska1972, s. 23, 26-27, 31-32, 46-48, 60-61, 86-90.

12 Skowron 2016, 51-52, s. 291-292; Leitsch 2009, III, s. 1610-161 
Dla Zygmunta III narodziny dzieci stawały się znakomitym pretekstem do poprawy stosunków z Filipem II Habsburgiem na tronie Hiszpanii, który od czasu elekcji i uwięzienia arcyksięcia Maksymiliana nie utrzymywał kontaktów z Zygmuntem III i nie ratyfikował traktatów bytomsko-będzińskich. Nawet ślub króla z Anną Austriaczką nie zmienił stanowiska Filipa II. Niezrażony tym król szukał sposobów na nawiązanie wzajemnych relacji. Natychmiast po urodzeniu się królewicza Władysława wysłał do króla Katolickiego zaproszenie na chrzest syna, licząc, że deleguje on swojego posła na ceremonię ${ }^{13}$. Dwór madrycki nie zareagował. Następnym razem król zadziałał szybciej. Kiedy Anna był w piątym miesiącu ciąży, Waza zaprosił Filipa II na ojca chrzestnego mającego przyjść na świat dziecka i poinformował, że udzielenie sakramentu nastąpi w ostatnim dniu września ${ }^{14}$. Tym razem odpowiedź z Madrytu była pozytywna. Przedstawiciel króla Hiszpanii, admirał Aragonii Francisco de Mendoza, hrabia de Veragua, przybył jednak na dwór polski dopiero w styczniu 1597 roku, dlatego podczas chrztu Katarzyny (II) Filipa II zastępował kardynał Enrico Gaetano, legat papieski ${ }^{15}$. Drugim rodzicem chrzestnym królewny była cesarzowa-wdowa Maria, żona Maksymiliana II i siostra króla Hiszpanii. Ojcem chrzestnym Krzysztofa, który urodził się 10 lutego 1598 i tego samego dnia zmarł, został arcyksiążę Albert, gubernator Niderlandów, do którego zaproszenie na ceremonie zostało skierowane już 2 stycznia. W odpowiedzi na nie arcyksiążę informował, że wysłał z poselstwem do Polski wicehrabiego Ottavia Viscontiego ${ }^{16}$. Przybył on do Warszawy już po śmierci królowej Anny i jej syna.

Chrzestnymi urodzonego w grudniu 1607 Jana Kazimierza, pierwszego syna Zygmunta i Konstancji, mieli zostać cesarz Rudolf i Maria Bawarska. Być może jego matką chrzestną była też królowa hiszpańska Małgorzata, siostra Konstancji, na co zdaje się wskazywać zapis w kronice Krzysztofa Zelnera o przyjeździe do Krakowa na święto Trzech Króli 1608 r. posła hiszpańskiego z gratulacjami i upominkami ${ }^{17}$. W czasie przyśpieszonych uroczystości chrztu cesarza zastępował królewicz Władysław. Bardzo niepewne były dotychczasowe ustalenia dotyczące rodziców chrzestnych Jana Kazimierza, przyszłego króla Rzeczypospolitej. Dominujący podgląd, że ojcem chrzestnym był kasztelen krakowski Janusz Ostrogski, budzi wiele wątpliwości z powodu zasad, jakie stosował Zygmunt III przy wyborze kumów $^{18}$. Z odnalezionych w hiszpańskim archiwum w Simancas dokumentów jednoznacznie wynika, że król zaprosił na chrzestnych Jana Kazimierza Filipa III

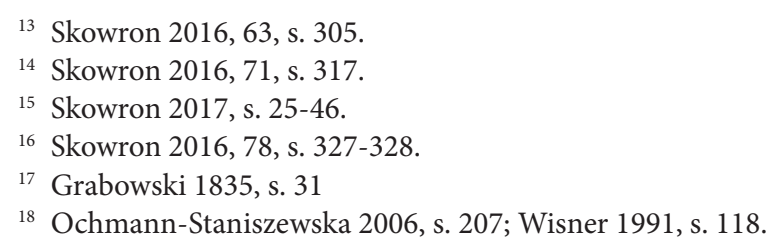


i jego małżonkę Małgorzatę. Już w pierwszej połowie lutego 1609 r. na posiedzeniu hiszpańskiej Rady Państwa omawiano, w odpowiedzi na list Zygmunta III z 15 listopada 1608, kwestię wybór ambasadora nadzwyczajnego, który udałby się do Polski, aby reprezentować hiszpańskiego Habsburga na uroczystościach chrztu ${ }^{19}$. Z kolei w marcu Filip II pisał do Wazy:

wysyłam hrabiego Morón, któremu nakazałem wyjazd do Waszego Majestatu, aby reprezentował mają osobę w funkcji ojca chrzestnego, złoży Waszym Majestatom od królowej i ode mnie gratulacje z okazji szczęśliwych narodzin, w co wierzymy i ofiaruje Królowej wstęgę i naszyjnik z diamentami na znak miłości, jaką do niej mamy ${ }^{20}$.

Z powodu nieprzybycia dyplomaty hiszpańskiego na uroczystości zastępował go Ostrogski. Na ojca chrzestnego Jana Kazimierza zaproszono również księcia bawarskiego Wilhelma V.

Zygmunt III systematycznie dążył do mocniejszego powiązania sieci rodzinno-dworskiej, wykorzystując do tego celu chrzciny swoich dzieci. Dobrze to pokazuje uczynienie kumami małoletniego króla Francji Ludwika XIII i jego matki królowej-wdowy Marii Medycejskiej, której matka była Habsburżanką, a babka Jagiellonką. To ich, wraz z arcyksięciem Ferdynandem i jego małżonką Maria Anną Wittelsbach, król zaprosił na rodziców chrzestnych urodzonego w roku 1612 królewicza Jana Alberta. Zaproszenie władcy francuskiego i jego matki jest dobrze udokumentowane w niezależnych źródłach ${ }^{21}$, dlatego zaskakujący jest fakt ich ponownego zaproszenia na rodziców chrzestnych urodzonego półtora roku później królewicza Karola Ferdynanda, którego ojcem chrzestnym został również cesarz Maciej. Podczas ceremonii królewicz Władysław zastępował francuskich rodziców chrzestnych, natomiast cesarza reprezentował specjalny poseł Jan Proskovšký z Krohensteina. Kolejnym, nowym dworem na mapie powiązań chrzcielnych stała się Florencja. Ojcem chrzestnym Aleksandra Karola został bowiem wielki książę Toskanii Kosma II, którego żoną była Maria Magdalena, siostra królowej Konstancji, natomiast na matkę chrzestną wybrano cesarzową Annę Tyrolską ${ }^{22}$. Z kolei rodzicami chrzestnymi urodzonej w styczniu 1616 r. Anny Konstancji zostali arcyksiążę Maksymilian, rywal Zygmunta III podczas trzeciej elekcji, oraz książę Bawarii Maksymilian I wraz z małżonką Elżbietą Lotaryńską. Anna Katarzyna Konstancja, ostatnie dziecko Zygmunta III i Konstancji, miała za matkę chrzestną Izabelę, gubernatorkę Niderlandów, a za ojca chrzestnego Leopolda V Tyrolskie-

19 González Cuerva 2016, s. 133, Leitsch 2009, III, s. 1729-1730.

20 Skowron 2016, 193, s. 205.

${ }^{21}$ Zob. m.in. Biblioteka Czartoryskich w Krakowie (dalej BCK), rkps 107, s. 57-59; Leitsch 2006, III, s. 1745-1746.

${ }^{22}$ Zob. Meysztowicz i Wyhowska 1972, s. 28, 45-49. 
go, biskupa Strasburga i Pasawy. Tym razem na ceremonię zdążyli przybyć ich wysłannicy: hrabia de Solre, reprezentujący Izabelę, oraz hrabia Adolf von Althan, przedstawiciel Leopolda $\mathrm{V}^{23}$.

Władysław IV w doborze rodziców chrzestnych kontynuował politykę ojca. Nie miał jednak takich możliwości, ponieważ z jego związku z Cecylią Renatą przyszło na świat tylko dwoje dzieci, a z drugą żoną Ludwiką Marią nie doczekał się potomka. Rodzicami chrzestnymi jego pierworodnego syna Zygmunta Kazimierza została para cesarska: Ferdynand III, w czasie uroczystości zastąpił go królewicz Karol Ferdynand, oraz jego małżonka Maria Anna, córka Filipa III, reprezentowana przez królewnę Annę Katarzynę Konstancję ${ }^{24}$. Na ojca chrzestnego drugiego dziecka Anny Marii Izabeli wybrał Filipa IV. Kiedy królowa ponownie była w ciąży, 19 sierpnia 1641 r., na cztery miesiące przed spodziewanym rozwiązaniem, Władysław IV wysłał list do króla Hiszpanii zapraszający go na ojca chrzestnego. W niecałe trzy miesiące później dwór madrycki podjął decyzję, że do Polski nie zostanie z tej okazji wysłane poselstwo, a Filipa IV będzie w czasie obrzędu będzie reprezentował Jan Kazimierz lub Adam Kazanowski² ${ }^{25}$ W 1643 r. Cecylia Renata ponownie była w ciąży. Wówczas Waza zwrócił się do królowej francuskiej Anny Austriaczki, siostry Filipa IV, aby została matką chrzestną mającego przyjść na świat dziecka. Królowa 23 marca 1644 r. urodziła martwego syna, a następnego dnia zmarła.

Władysław IV zmarł w 1648 r., a w rok po jego śmierci trzydziestoośmioletnią Ludwikę Marię poślubił król Jan Kazimierz ${ }^{26}$. Wiek królowej powodował, że para nie mogła liczyć na liczne potomstwo. Kiedy królowa w lipcu 1650 powiła córkę Marię Annę Teresę, Jan Kazimierz poszedł w ślady swoich poprzedników, zapraszając na rodziców chrzestnych cesarza Ferdynanda III i jego żonę Eleonorę. W trakcie uroczystości zastępowali ich królewicz Karol Ferdynand i podkanclerzyna Teodora z Tarnowskich Sapieżyna. W dwa lata później królowa urodziła syna Jana Zygmunta - na jego matkę chrzestną zaproszono królową Szwecji Krystynę i był to jedyny przypadek, kiedy rodzicem chrzestnym został członek szwedzkiego rodu Wazów.

\section{SPOTKANIA RODZINNE: WAZOWIE W PODRÓŻACH}

Pierwszy etap nawiązania bezpośrednich relacji, spotkania twarzą $\mathrm{w}$ twarz członków przyszłej rodziny, stanowiły uroczystości weselne. Wraz z arcyksiężniczką Anną do Krakowa przybyła jej matka Maria Bawarska, aby wziąć udział

\footnotetext{
${ }^{23}$ Ibidem, s. 87.

${ }^{24}$ Radziwiłł 1980, II, s. 199.

25 Archivo General w Simancas, E. 2342, f. 7 i 8.

${ }^{26}$ Kraszewski 2007, s. 124-132.
} 
w ceremonii zaślubin i koronacji córki. W ten sposób Zygmunt III już na początku małżeństwa miał możliwość poznania swojej teściowej, z którą w następnych latach utrzymywał bliskie relacje, pisząc do niej nawet listy w języku niemieckim² ${ }^{27}$. Już w jednym z pierwszych listów król pisał:

Jako że WM myśli, że wkładam wiele trudu, aby do WM tak często pisać, to jest to dla mnie naprawdę żaden trud, czynię to chętnie, obawiam się jednak czy WM nie obarczam dużym trudem w [odczytaniu] mojego niemieckiego pisma i całkowitym jego zrozumieniu ${ }^{28}$.

Maria, starannie wykształcona, znająca łacinę i uwielbiająca muzykę, była żarliwą katoliczką, troskliwą, ale i despotyczna matką, która zawsze wspomagała swoje dzieci. W odwiedziny do córki i zięcia w Polsce ponownie przybyła w 1595 roku w drodze powrotnej z Węgier, gdzie brała udział w ślubie córki Marii Krystyny z Zygmuntem Batorym. Cztery lata później uczestniczyła w Krakowie w uroczystościach pogrzebowych Anny i przez kilka dni przebywała z Zygmuntem III w Niepołomicach, a jednym z tematów ich rozmów mogła być sprawa nowego małżeństwa owdowiałego króla. W 1605 roku Maria wraz z arcyksięciem Ferdynandem po raz czwarty przybyła do Polski na ślub córki Konstancji. Ich udział w uroczystym wjeździe do Krakowa utrwalony został na rolce sztokholmskiej ${ }^{29}$. Cecylii Renacie w drodze do Polski i podczas uroczystości weselnych towarzyszyła ciotka arcyksiężna Klaudia Florentyna Medycejska, regentka Tyrolu, wdowa po Leopoldzie $\mathrm{V}^{30}$. Przyjazdowi Ludwiki Marii Gonzago do Polski nie towarzyszył nikt $z$ jej rodziny.

Bardzo ograniczony zasięg miały spotkania rodzinne Wazów polskich z krewnymi z linii szwedzkiej rodu. Zygmunt III po wyborze na króla Polski tylko raz spotkał się ze swoim ojcem podczas zjazdu w Rewlu w roku $1589^{31}$. Spotkanie było trudne i przebiegało $w$ napiętej atmosferze, ponieważ jednym $z$ celów Jana III było zmuszenie syna do powrotu do Szwecji. Król Szwecji na zjazd z synem zabrał żonę Gunillę i kilkumiesięcznego syna Jana. Do największego spotkania Zygmunta III z krewnymi szwedzkimi doszło w roku 1593 po śmierci króla Jana III. W ostatnim dniu września król wraz z małżonką Anną i siostrą Anną dotarli do Szwecji. Najpierw wzięli udział w pogrzebie Jana III, a 19 lutego 1594 r. w Uppsali odbyła się koronacja królewska Zygmunta III i jego żony. Oba wydarzenia zgromadziły dużą

${ }^{27}$ W Haus-, Hof- und Staatsarchiv w Wiedniu (dalej HHStA) w zbiorze Familienkorespondenz A, 41 znajduje się szesnaście niemieckojęzycznych listów Zygmunta III do Marii Bawarskiej z lat 1592-1601.

${ }^{28}$ HHStA, Familienkorespondenz A, 41, k. 9-10.

29 Relacje łączące Zygmunta III z Marią Bawarską pomimo opracowania Leitscha 2009, zwłaszcza III, s. 1581-1605, zob. też Keller 2012, s. 155-157, Kadzik 2017.

${ }^{30}$ Falniowska-Gradowska 1991, s. 13, 47-70, 73.

31 Lepszy 1939, s. 55-80. 
liczbę członków rodu Wazów, zarówno żyjących w tym królestwie, jak i mieszkających poza jego granicami. Król mógł się spotkać m.in. z przyrodnim, liczącym pięć lat, bratem Janem, królową-wdową Gunillą, wujem Karolem Sudermańskim z żoną Krystyną Holstein-Gottorp i jego córką z pierwszego małżeństwa Katarzyną, wujem Magnusem, ciotką Zofię i jej synem Gustawem, którzy zostali wygnani z Saksonii Lauenburg, ciotką Elżbietą, wdową po Krzysztofie Meklemburskim, i jej córką Małgorzatę ${ }^{32}$. Królowa Anna mogła zaś ich wszytkich poznać. Było to pierwsze i zarazem ostanie tak wielkie spotkanie polskiego Wazy z krewnymi szwedzkimi.

Zygmunt III utrzymywał stosunkowo bliskie relacje z ciotkami Cecylią i Katarzyną oraz ich dziećmi, zwłaszcza z tymi, które przeszły na katolicyzm. Cecylia, o której rękę zabiegał Jan Tęczyński, poślubiła Krzysztofa II, margrabiego Baden-Rodemachern. Po śmierci męża w 1577 r., aby utrzymać jego dziedzictwo, przeszła na katolicyzm ${ }^{33}$. Pozostawała w bliskich kontaktach $\mathrm{z}$ dworem madryckim i często odwiedzała Brukselę. Jej syn Edward Fortunat przebywał na dworze polskim w latach 1587-1589, a w 1598 r. towarzyszył Zygmuntowi III w wyprawie do Szwecji ${ }^{34}$. Najprawdopodobniej pierwszy raz ciotka odwiedziła bratanka w Polsce w 1592 r. Na pewno była na dworze Zygmunta III pięć lat później, bo z maja 1597 r. pochodzą listy króla i jego małżonki do cesarza Rudolfa II polecające mu sprawy Cecylii ${ }^{35}$. Zygmunt III utrzymywał kontakty z swoimi krewnymi z Fryzji Wschodniej - dziećmi Katarzyny Wazy i Edzarda II, którzy w obronie praw do posiadłości po ojcu przyjęli katolicyzm (Jan i Krzysztof). Na ślub tego pierwszego w 1601 r. z Sabiną Katarzyną Crikseną, dziedziczką hrabstwa Rietberg, król wysłał Pawła Działyńskiego ${ }^{36}$. Polskiemu Wazie szczególnie bliski był kuzyn Krzysztof, hrabia Emden, przebywający na dworze polskim w 1599 r. Utrzymywał z nim korespondencję i popierał jego sprawy u arcyksięcia Alberta, gubernatora Niderlandów. W 1613 r. Krzysztof poślubił Lambertynę de Ligny, córką Lamorala hrabiego de Ligny, który w 1601 r. w imieniu Filipa III przywiózł Zygmuntowi III Order Złotego Runa. Zapewne to małżeństwo i pamięć o ojcu Lambertyny spowodowały, że król zwrócił się do władcy Hiszpanii o nadanie tego orderu Krzysztofowi ${ }^{37}$. Po śmierci Jana III i szwedzkiej koronacji Zygmunta III do Polski powrócił wspomniany już wyżej Gustawa Eryksson Waza. W 1599 r. wyjechał do Moskwy na

${ }^{32}$ Spotkanie rodzinne w czasie pobytu polskiej pary królewskiej w Szwecji szczegółowo ukazują listy królowej Anny do Marii Bawarskiej: HHStA, Familienkorespondenz A, 40-3, które opublikowała Dobner 2015.

33 Ödberg 1896, s. 157-178.

${ }^{34}$ Leitsch 2009, II. s. 793.

35 Skowron 2016, 75, s. 323-324 oraz HHStA, Polen I 87, k. 372-373.

${ }^{36}$ Ratsbücherei w Lüneburgu, Ms. Hist. C 2º 32, k. 327.

${ }^{37}$ Skowron 2015, 104-105, s. 239-242. 
zaproszenie Borysa Godunowa i pozostał tam do końca życia. Detronizacja Zygmunta III przez Riksdag w 1599 r., a następnym roku uchwała pozbawiająca praw do tronu Szwecji jego potomków, oznaczała nie tylko zerwanie polsko-szwedzkiej unii personalnej i rozpoczęcie wojny między obu państwami, ale również zerwanie wszelkich osobistych kontaktów między członkami rodu Wazów zasiadającymi na tronach w Sztokholmie i Warszawie.

Zygmunt III, poza przybywającymi do Polski na jego śluby z Anną i Konstancją, poznał osobiście spośród członków Domu Austrii jedynie arcyksięcia Karola, biskupa Wrocławia i Brixen. Przybył on do Warszawy w 1616 r. na chrzciny Anny Konstancji, podczas których zastępował arcyksięcia Maksymiliana w roli ojca chrzestnego. Ponownie zjawił się w Polsce pod koniec września 1619 r., kiedy stany śląskie, po wybuchu powstania czeskiego, uznały Fryderyka V Wittelsbacha za króla. Na dworze Wazów biskup wrocławski przebywał ponad rok, zabiegając u szwagra o wsparcie wojskowe w walce ze zbuntowanymi poddanymi. Wdzięczny za pomoc i gościnę Karol mianował swoim koadiutorem królewicza Karola Ferdynanda. Na Śląsk powrócił dopiero po klęsce powstańców pod Białą Górą ${ }^{38}$.

Nowe możliwości bezpośredniego spotkania Wazów z krewnymi rozrzuconymi po całej Europie stwarzały podróże zagraniczne. Zgoda Zygmunta III na wyjazd królewicza Władysława na Zachód stała się precedensem, dzięki któremu możliwe były późniejsze peregrynacje jego braci: Jana Kazimierza, Jana Alberta i Aleksandra Karola. W realizacji podczas podróży celów edukacyjno-poznawczych, religijnych czy politycznych szczególną rolę pełniły spotkania rodzinne. To dwory krewnych tworzyły węzłowe punkty na trasie ich podróży. Kontekst rodzinny w peregrynacjach Wazów to specyficzny element, który zasadniczo odróżnia je od wyjazdów synów magnackich ${ }^{39}$.

Momentem przełomowym w bezpośrednich spotkaniach Wazów z Habsburgami była wielka podróż królewicza Władysława po Europie w latach 1624-1625. Młody Waza jeszcze w obozie pod Chocimiem ślubował pielgrzymkę do Loreto. Wobec sprzeciwu Zygmunta III Władysław zwrócił się o poparcie do krewnych, m.in. do cesarza Ferdynanda II, biskupa wrocławskiego Karola Habsburga, i jak podaje Stefan Pac:

Ci tedy obaj pisali do króla i do Królowej Jej Mci gorąco prosząc, aby siostrzeńcowi ich nie bronił wyjechać wprzód do nich samych, a potem i do inszych powinnych i dalej do cudzych krajów... Więc i arcyksiężna Infantka hiszpańska, która w Belgium rządzi, pisała też snadź do Królestwa Ich Mci, życząc sobie poznać Królewica ${ }^{40}$.

${ }^{38}$ Mosbach 1869, s. 218-232.

${ }^{39}$ Nie podzielam poglądu U. Augustyniak 1999, s. 157, która uważa, że w peregrynacjach zagranicznych królewicze byli w podobnym położeniu jak synowie magnatów.

40 Przyboś 1977, s. 40. 
Jednym z ważnych celów Grand Tour Władysława było poznanie krewnych mieszkających we Wrocławiu, w Wiedniu, w Innsbrucku, w Monachium, w Brukseli i we Florencji. Podkreślić należy, że nie tylko w sferze kultury peregrynacja królewicza, jak pisała Karolina Targosz, „wytyczy drogi jego mecenasowskiej działalności i nada zdecydowane piętno polskiej kulturze dworskiej w dobie jego panowania"41 ale również w znacznym stopniu wyznaczy kierunki jego przedsięwzięć politycznych na Zachodzie. Cele dynastyczno-polityczne i propagandowe podróży wydają się mieć zasadnicze znaczenie. Królewicz miał zabiegać o małżeństwo z infantką Marią Anną, córką króla Hiszpanii Filipa III, i o pomoc Habsburgów w odzyskaniu tronu szwedzkiego ${ }^{42}$.

W trakcie podróży Władysław spotkał się w Nysie z biskupem Karolem i razem udali się oni na dwór cesarski. W Wiedniu był gościem cesarza Ferdynanda II i jego drugiej żony Eleonory Gonzagi. Poznał też dzieci cesarza z pierwszego małżeństwa z Marią Anną Wittelsbach: Ferdynanda i Leopolda Wilhelma oraz ich córki Marię Annę i trzynastoletnią Cecylię Renatę, swoją przyszłą żonę. W Wiedniu i Strasburgu królewicz spotkał się z arcyksięciem Leopoldem V. Bardzo uroczyście był podejmowany w Brukseli przez infantkę Izabelę ${ }^{43}$. We Florencji zatrzymał się na dworze ciotki arcyksiężnej Marii Magdaleny, wdowy po Kosmie II, i jej syna, wielkiego księcia Toskanii Ferdynanda II, poznał też jego młodszych braci Giana Carla i Leopolda.

Peregrynując po Europie, królewicz odwiedzał nie tylko najbliższych krewnych z rodu Habsburgów, ale również tych dalszych. W Monachium gościł go brat babki Marii Wilhelm V Wittelsbach i jego syn Maksymilian I, książę Bawarii i elektor Palatynatu Reńskiego. W Bonn poznał zaś braci Maksymiliana Ferdynanda, arcybiskupa i elektora Kolonii oraz Albrechta, księcia Bawarii-Lauchtenberg.

W czasie poznawania Niderlandów i krajów nadreńskich Władysław miał również możliwość spotkania się z potomkami Wazów szwedzkich po kądzieli, dziećmi i wnukami ciotek Zygmunta III. W diariuszach uczestników podróży Stefana Paca i Jana Hagenawa znajduje się lakoniczna wzmianka, że w uczcie wydanej przez arcybiskupa Leopolda w Saverne uczestniczyli „margrafowie badeńscy dwaj bracia"44. Byli nimi Herman Fortunat i Wilhelm, margrabiowie Badem-Rodemachen, synowie wspomnianego wyżej Edwarda Fortunata, a wnukowie Cecylii Wazy. Warto w tym miejscu odnotować, że syn margrabiego Wilhelma Herman von Baden-Baden na początku lat 60 . XVII był wymieniany wśród kandydatów do korony polskiej, gdyby doszło do abdykacji Jana Kazimierza, i blisko współpracował z królem Janem III Sobieskim w czasie odsieczy Wiednia. Dodatkowe

\footnotetext{
41 Targosz-Kretowa 1965, s. 36.

42 Skowron 2002, s. 106-107; González Cuerva 2016, s. 142.

43 Szmydki 2002, passim.

44 Przyboś 1977, s. 212.
} 
informacje o pobycie w otoczeniu Władysława krewnych z domu Wazów zawiera sztambuch Adama Kazanowskiego. Wpisali się do niego syn Katarzyny Wazy Krzysztof, hrabia Emden, i jego żona Lambertyna ${ }^{45}$.

Wszyscy krewni, bliżsi i dalsi, przyjmowali Władysława bardzo życzliwie i z wielką gościnnością, i tak organizowali pobyt na swoich dworach, aby mu zapewnić godne jego osoby uczty, rozrywki i widowiska. W towarzystwie krewnych królewicz poznawał ich pałace, ogrody i zwierzyńce, pełne dzieł sztuki i curiositates skarbce i kunstkamery, brał udział $\mathrm{w}$ widowiskach teatralnych i muzycznych, uczestniczył w mszach i polowaniach. Często krewni osobiście oprowadzali królewicza po swoich kolekcjach, np. w Wiedniu:

zaprowadzony został do sekretnego skarbca domu austriackiego, gdzie oglądał nagromadzone przez tylu cesarzy i arcyksiążąt bogactwa i perły rozmaitymi, budzącymi podziw rarytasami i nieporównywalnymi cudami natury i sztuki; sam cesarz wszystko pokazywał i objaśniał ${ }^{46}$,

w Brukseli:

po obiedzie jeździł z Infantą za miasto do miejsca jednego nabożnego Pannie Najświętszej; zowią je Beata Virgo Lachensis. A ten sposób nalazła była Infanta miastu wszystkiemu ukazać, czego lud pospolity sobie bardzo życzył ${ }^{47}$,

zaś we Florencji:

po obiedzie w cesarskiej willi Najjaśniejszej Arcyksiężny, blisko miast, jej kosztem wystawiono komedię o Rugerze, Alcynie i Melissie z przepiękną wstawą i grą. Sama Najjaśniejsza Arcyksiężna z pomocą jw. kardynała Medyceusza pilnie brała udział przy wprowadzaniu do teatru i wyznaczaniu miejsc przewidzianych dla zaproszonych gości [następnego dnia] po mszy w kościele katedralnym wszedł Królewicz z W. Księciem i wieloma z jego orszaku na kopułę świątyni ${ }^{48}$.

Spotkania bezpośrednie Władysława z członkami rodziny wywoływało również reakcje emocjonalne. W liście do królowej Konstancji jej brat cesarz Ferdynand II pisał, że królewicz: „Zaprawdę jest on wytwornym i szlachetnym księciem - zarówno po jego twarzy, jak i po gestach doskonale widać, kim była jego matka"49, a siostra Maria Magdalena stwierdzała:

\footnotetext{
${ }^{45}$ Rastawiecki 1853, s. 468.

46 Przyboś 1977, s. 79.

47 Ibidem, s. 170.

${ }^{48}$ Ibidem, s. 346.

49 Żukowski 2015, s. 117.
} 
jest on niezwykle wytwornym, przystojnym i wyrozumiałym mężem i nie mógłby się wyprzeć swojego pochodzenia z naszej dynastii. Dalej zaś można powiedzieć, że książę zupełnie przypomina cesarza $\mathrm{i}$ jest $\mathrm{w}$ pełni taki sam, jak on był w jego wieku ${ }^{50}$.

Władysław ponownie wyjechał zagranicę w 1638 r. już jako król Polski. W towarzystwie żony Cecylii Renaty i swej siostry Anny Katarzyny Konstancji udał się na kurację leczniczą do Baden, położonego blisko Wiednia. Wyjazd Wazy do wód, chociaż miał charakter leczniczy, stwarzał też możliwość bliższego poznania rodziny i dworu cesarskiego oraz podjęcia dyskusji na temat współpracy politycznej m.in. w sprawie europejskich rokowań pokojowych oraz niewoli francuskiej Jana Kazimierza $^{51}$. Spotkania rodzinne w czasie pobytu polskiej pary królewskiej w Baden organizowały cesarzowa Maria Anna i cesarzowa-wdowa Eleonora Gonzaga oraz brat Cecylii Renaty arcyksiążę Leopold Wilhelm.

W trakcie pobytu w Austrii jednym z najbardziej drażliwych i kontrowersyjnych zagadnień były kwestie proceduralne. Król i jego najbliżsi doradcy przywiązywali dużą wagę do tego, aby w trakcie ceremonialnych spotkań nie został naruszony prestiż ani honor władcy polskiego. Władysław był niechętnie nastawiony do spotkań z Marią Anną. Kiedy orszak królewski zmierzał do Baden i dotarł do Wolkersdorfu, nadeszło od cesarzowej zaproszenie na obiad. Jakub Sobieski tak opisał to pierwsze spotkanie polskiej rodziny z żoną Ferdynanda III:

Potem na pół wschodu wyszła cesarzowa, w perłach tylko wszytka ubrana. Król JM, lubo z drogi, ale się też także kosztownie ubrał i królowa, i królewna Jej Mość także. Mówił król JM do cesarzowej po włosku, która dosyć go przyjęła mile i odpowiedziała mu po hiszpańsku krótko. Obłapiła się po tym bardzo mile z królową Jej Mością i z królewna tak się ścisnęła, że zausznice jej perłowe z zausznicami królewny aż się z sobą poplątali, że ich odrywać musiano. Prosiła potym króla JM, aby wszedł dalej. I szedł. Potym uczyniła kortezyją, prosząc królowej Jej Mości, aby szła za królem JM, ale królowa Jej Mość żadną żywą miarą nie chciała. I tak cesarzowa, wziąwszy się z królową i z królewną za ręce, szli razem wszytkie trzy za królem JM ${ }^{52}$.

Władysław IV spotkał się z Ferdynandem III dopiero w Nikolsburgu, w drodze powrotnej do kraju. Cesarz swym zachowaniem jeszcze bardziej zraził do siebie króla polskiego:

zszedli do siebie król JM z królową i królewną do cesarza, a cesarz z arcyksiążęciem Leopoldem do królestwa naszego. I tak na polu. Na zagonie jednym, przywitali się z sobą dość mile... Potym zaprosiwszy cesarza królestwa naszego do swej karety, bez wszelkiej ceremo-

\footnotetext{
50 Ibidem s. 115-116.

51 Skowron 2013, s. 204-210.

52 Sobieski 1991, s. 234.
} 
nijej i bez wstydu biegł wprzód przez zagony do swej karety, bojąc się podobno, żeby król JM pierwszej mu ręki nie wziął i wprzód nie wsiadł do karety. I tak wprzód wsiadwszy na pierwsze miejsce do karety, króla JM drugim miejscem częstował ${ }^{53}$.

Za życia Zygmunta III żaden z jego synów, poza Władysławem, nie odbył podróży zagranicznej. Nawet królewicz Karol Ferdynand po osiągnięciu pełnoletności nie wyjechał na Śląsk, aby osobiście przejąć rządy w diecezji wrocławskiej. Wkrótce po objęciu tronu Władysław IV nie tylko aprobował wyjazdy swoich młodszych braci, ale też powierzał im realizację zadań politycznych i prowadzenie spraw rodzinnych. Już w lipcu 1633 r. najmłodszy z nich Aleksander Karol wyruszył w podróż do Hiszpanii. W trakcie peregrynacji po Włoszech królewicz zrezygnował z wyjazdu na dwór madrycki. Zapewne jednym z powodów było odrzucenie przez Filipa IV jego zabiegów o rękę pięknej Anny Caraffy, księżniczki Stigliano, które prowadził podczas pobytu w Neapolu ${ }^{54}$. Po półtoramiesięcznym pobycie w Rzymie królewicz udał się do Florencji, gdzie spotkał się ze swoimi krewnymi z domu Medyceuszy, którzy dziewięć lat wcześniej gościli Władysława Wazę. Od tamtego czasu na dworze toskańskim zaszły istotne zmiany: wielki książę Ferdynand II objął samodzielne rządy i poślubił Wiktorię della Rovere, nie żyła już ciotka Wazów Maria Magdalena Habsburg. We Florencji, podobnie jak w Rzymie, przyjmowano królewicza bardzo uroczyście. Do Livorno, skąd królewicz miał odpłynąć statkiem do Genui, odprowadzał go Lorenzo Medici, brat Kosmy II.

Do kolejnego spotkania rodzinnego doszło w Mediolanie, gdzie przebywał wówczas kardynał-infant Ferdynand, brat Filipa IV. Pobyt królewicza odnotował sekretarz króla hiszpańskiego Diego de Aedo y Gallarte, który w dzienniku podróży Ferdynanda do Niderlandów pisał:

W końcu marca przybył do Mediolanu brat króla polskiego Władysława, kuzyn Jego Wysokości [Ferdynanda], którego ugościł wspaniale w pałacu i kilka razy wspólnie jedli; był dwanaście dni i Jego Wysokość podarował mu sześć koni z bogatymi rzędami i inne rzadkie i wartościowe przedmioty ${ }^{55}$.

Podczas peregrynacji Karol Aleksander dwukrotnie odwiedził Wiedeń - spędził tu łącznie ponad trzy miesiące. Poznał Ferdynanda II i jego żonę Eleonorę oraz dzieci cesarza z pierwszego małżeństwa z Marią Anną. W maju 1634, tuż przed wyjazdem do kraju, przez kilka dni przebywał z wujem w Laxenburgu. Po powrocie Karola Aleksandra do kraju na peregrynację po Zachodniej Europie wyruszył jego brat kardynał Jan Albert, który również planował dotrzeć do Hiszpa-

\footnotetext{
53 Ibidem, s. 261-262.

54 Skowron 2012, s. 443-451.

55 Aedo y Gallart de 1635, s. 71.
} 
nii ${ }^{56}$. Cele podróży są okryte tajemnicą. Królewicz, jadąc do Włoch, nie udał się na dwór cesarski. Jedynie będąc w Winner Neustadt, napisał do wuja list z przeprosinami, że nie może go odwiedzić. Jan Albert na dłużej zatrzymał się w Padwie i tu nagle zmarł 29 grudnia $1634 \mathrm{r}$.

Jan Kazimierz był tym Wazą, który odbył najwięcej podróży na Zachód. Pierwsze podróże do Wiednia miały oficjalnie cele rodzinne, w rzeczywistości jednak były istotną częścią rokowań Władysława IV z cesarzem w sprawie pomocy w odzyskaniu tronu szwedzkiego. W lutym 1635 królewicz udał się na dwór cesarski na chrzciny Marianny, córki króla Czech i Węgier Ferdynanda III i Marii Anny ${ }^{57}$. Podczas uroczystości zastępował Władysława IV, co zdaje się wskazywać, że król został zaproszony na ojca chrzestnego. Jan Kazimierz ponownie znalazł się w Wiedniu w lipcu tego roku na ślubie córki cesarza Ferdynanda II, arcyksiężniczki Marii Anny, z księciem Bawarii Maksymilianem I. Towarzyszył młodej parze w drodze powrotnej do Bawarii, po czym udał się nad Ren, gdzie jako dowódca regimentu cesarskiego, walczył z Francuzami i Szwedami. Na żądanie króla powrócił do Polski pod koniec 1635 r. Królewicz ponownie wyjechał do Wiednia w 1637 r. gdzie w imieniu Władysława IV 9 sierpnia poślubił per procura Cecylię Renatę, której towarzyszył w drodze do Polski.

W 1638 r. Jan Kazimierz wyruszył do Hiszpanii, gdzie miał objąć urząd wicekróla Portugalii ${ }^{58}$. Do spotkania z bratem ciotecznym Filipem IV i jego rodziną jednak nie doszło, ponieważ królewicz w czasie postoju w jednym z portów francuskich został aresztowany przez władze francuskie. W niewoli przebywał prawie dwa lata. Po opuszczeniu więzienia krótko przebywał na dworze Ludwika XIII. Podczas tej wizyty poznał przyszłą swoją żonę Ludwikę Marię Gonzagę ${ }^{59}$. W drodze powrotnej zatrzymał się w Brukseli, gdzie był uroczyście podejmowany przez kardynała-infanta Ferdynanda, brata króla Hiszpanii. Było to już drugie spotkanie hiszpańskiego Habsburga z polskim Wazą.

Ponownie w podróż zagraniczną Jan Kazimierz wyjechał w 1642 r. po uroczystościach ślubnych siostry Anny Katarzyny Konstancji i Filipa Wilhelma. Odprowadzał parę młodą aż do Düsseldorfu. Po drodze małżonkowie i królewicz odbyli w Laxenburgu spotkanie z cesarzem Ferdynandem III i jego małżonką Marią Anną ${ }^{60}$. W następnym roku Jan Kazimierz wyruszył na pielgrzymkę do Loreto, podczas której wstąpił do zakonu jezuitów. Jak zawsze w podróżach Wazów na Zachód Europy zatrzymał się Wiedniu, gdzie rozmawiał z cesarzem Ferdynandem

\footnotetext{
${ }^{56}$ Grabowski 1845, s. 24-25.

${ }^{57}$ Wasilewski 1984, s. 12-13, błędnie podaje, że na chrzciny Ferdynanda, wnuka cesarza Ferdynanda II.

58 Skowron 2013, s. 195-249; Conde Pazos 2011, s. 123-139.

59 Serwański 1986, s. 266-268.

60 Żukowski 2017, s. 248.
} 
III. W drodze do Włoch wstąpił jeszcze do Innsbrucka, gdzie spotkał się z arcyksięciem Ferdynandem Karolem i jego matką Klaudią Medicii. Po opuszczeniu zakonu i powrocie do kraju królewicz ponownie w maju 1648 r. wyjechał do Austrii. Tym razem podróż wiązał się z jego planami matrymonialnymi, zamierzał bowiem poślubić córkę arcyksięcia Leopolda V Tyrolskiego i Klaudii Medici arcyksiężniczkę Izabelę Klarę, której siostra Maria Leopoldyna miała w lipcu zostać żoną cesarza. W czasie pobytu w Wiedniu otrzymał wiadomość o śmierci Władysława IV i natychmiast powrócił do kraju. Aktywność i bliskie związki Jana Kazimierza z Domem Austrii w latach 1635-1648 zdają się wskazywać na mocne funkcjonowanie w mentalności królewicza również tożsamości habsburskiej.

\section{ZOBOWIĄZANIA DYNASTYCZNE - URZĘDY, BENEFICJA I ORDERY}

Zgodnie z normami ustrojowymi Rzeczpospolitej synowie królów elekcyjnych nie posiadali statusu następcy tronu, a ich prawa były bardzo ograniczone. Ich sytuacji nie zmieniał fakt, że formalnie byli dziedzicami korony szwedzkiej. Nie mogli pełnić funkcji państwowych, zasiadać w senacie czy posiadać dóbr dziedzicznych, co zamykało im drogę do kariery świeckiej w Rzeczypospolitej ${ }^{61}$. Jedynym wyjątkiem były nominacje na urzędy biskupie Jana Alberta i Karola Ferdynanda, do których doprowadził Zygmunt III pomimo sprzeciwu szlachty. Królewicze, dopóki żył ich ojciec, byli na jego utrzymaniu. Po śmierci Zygmunta III sejm $\mathrm{z}$ roku 1632 nadał im niewielkie dochody na starostwach niegrodowych. Dlatego też Władysław IV, zbiegając o poprawę sytuacji materialnej swoich braci, szukał pomocy u krewnych za granicą.

Więzy krwi i sytuacja polityczna, zwłaszcza po wybuchu wojny trzydziestoletniej, stwarzały Zygmuntowi III możliwości ubiegania się u krewnych w Wiedniu i Madrycie o urzędy i pomoc finansową dla synów. Pierwszym gestem wdzięczności Habsburgów za pomoc wojskową w walce z powstańcami czeskimi i dywersję wojskową w czasie oblężenia Wiednia przez Bethlena Gabora było ustanowienie w 1619 r. przez arcyksięcia Karola, biskupa wrocławskiego, swym koadiutorem królewicza Karola Ferdynanda. W sześć lat później, po śmierci biskupa, objął on rządy w diecezji wrocławskiej ${ }^{62}$. Wcześniej, jeszcze zanim na dwór polski dotarła informacja o śmierci w Hiszpanii biskupa wrocławskiego, królowa Konstancja zabiegała u swego kuzyna Ferdynanda Wittelsbacha, elektora Kolonii, o nadanie Karolowi Ferdynanda kanonikatu w tamtejszej katedrze ${ }^{63}$. Zygmunt III nie umiał lub nie chciał wykorzystać sytuacji, jakie stwarzała wojna, do uzyskania któregoś

\footnotetext{
61 Augustyniak 1999, s. 158-166.

62 Brzezińska-Laszczkowa 2008, s. 63-73.

63 Archiwum Główne Akt Dawnych, LL 30, k. 181.
} 
z księstw śląskich dla jednego z synów. Odwołując się do zasady legitymizmu, król przyjął wobec konfliktu w Rzeszy postawę neutralną, ale zdecydowanie życzliwą wobec Habsburgów, czego najlepszym przykładem była zgoda na ciągłe ponawianie zaciągów żołnierzy polskich. W zamian ofiarowali oni Wazom jedynie wyrazy przyjaźnie i składali mgliste obietnice pomocy królewiczom.

Nowe perspektywy pogłębienia współpracy dynastycznej powstały w czasie rokowań w sprawie małżeństwa króla polskiego z Cecylią Renatą. 14 grudnia 1636 roku Władysław IV i Ferdynand II zawarli traktat familijny, który został odnowiony 16 marca 1637 roku, po objęciu tronu cesarskiego przez Ferdynanda III ${ }^{64}$. Obie układające się strony, tj. Habsburgowie austriaccy i zygmuntowska linia Wazów, zobowiązywały się do ścisłej współpracy i wzajemnego zabezpieczania interesów dynastycznych. Cesarz podejmował się udzielić Władysławowi IV pomocy politycznej i wojskowej w odzyskaniu Szwecji. W wypadku zwycięskich wojen z Turcją zdobyty obszar miał być nadany w dziedziczne lub lenne posiadanie przedstawicielowi rodziny Wazów. Cesarz miał wspierać linię zygmuntowską poprzez małżeństwa, pensje i godności. W zamian Władysław IV, jako król szwedzki, przelewał na Habsburgów prawo do korony szwedzkiej po wygaśnięciu domu Wazów, a jako władca Szwecji i Polski zobowiązywał się do niezawierania układów sprzecznych z interesami Austrii. W kontrakcie małżeńskim nie udało się królowi wprowadzić zapisu zabezpieczającego posag Cecylii Renaty na księstwach śląskich: opolskim, raciborskim i cieszyńskim. Ostatecznie zostały zawarte umowy, w których sumy posagowe Cecylii Renaty oraz niewypłacone kwoty królowych Anny i Konstancji wysokości 300 tys. florenów reńskich zostały zapisane na dobrach Wittingau (Třeboň) na Morawach, jednak z możliwością przeniesienia ich w przyszłości na inne terytorium ${ }^{65}$. W $1645 \mathrm{r}$. Ferdynand III i Władysław IV podpisali traktat, na mocy którego dług finansowy cesarza został przeniesiony z dóbr morawskich na księstwo opolsko-raciborskie oraz klucz kozielski. Zastaw miał obowiązywać przez 50 lat, po którym to okresie cesarz mógł księstwa wykupić, zwracając całą dłużną sumę ${ }^{66}$. Pomimo mocno ograniczonych praw kolejno władający księstwami Wazowie: Władysław IV, Jan Kazimierz i Karol Ferdynand mogli się tytułować dux Opoliae et Rathiboriae. W 1655 r. Jan Kazimierz przekazał księstwa śląskie swojej żonie Marii Ludwice. Osiem lat później królowa zapisała je w posagu swojej siostrzenicy Annie, którą adoptowała w związku z jej małżeństwem z księciem d’Enghien, kandydatem do korony polskiej ${ }^{67}$. Cesarz Leopold I z obawy przed przeję-

\footnotetext{
64 Skowron 2013, s. 173-178.

65 Dzięgiel 1936, s. 26-28.

66 Leszczyński 1969, s. 13-45.

67 Dzięgiel 1936, s. 34-36.
} 
ciem księstwa opolsko-raciborskiego w 1666 r. wykupił je z rąk księcia d’Enghien za 1200000 florenów.

Coraz bliższa współpraca polityczna między Wazami a hiszpańskimi Habsburgami w latach 20. i 30. XVII wieku, zwłaszcza w odniesieniu do planu bałtyckiego hrabiego-księcia Olivaresa, a następnie sojuszu antyfrancuskiego, spowodowała, że związki rodzinne między obiema dynastiami zacieśniały się i obejmowały nowe obszary. Przedmiotem negocjacji stały się urzędy, beneficja i pensje dla członków rodziny Wazów. Z propozycjami w tym zakresie wychodził zarówno dwór warszawski, jak i madrycki. Wazowie oczekiwali, że za prohabsburską politykę zostaną odpowiednio wynagrodzeni. Chcieli w ten sposób zwiększyć swoje niewielkie dochody i uposażenie, jakie posiadali w państwie polsko-litewskim. Natomiast dwór madrycki w pomocy finansowej widział środek, za pomocą którego pozyska przychylność króla polskiego i członków jego rodziny Wazów podczas negocjacji politycznych.

Filip IV w trakcie rokowań z Zygmuntem III w latach 1627-1628 proponował, aby dowództwo nad budowaną wazowsko-habsburską flotą bałtycką objął królewicz Władysław, i zapowiadał udzielenie mu trzyletniego subsydium pieniężnego $^{68}$. Wyrażał gotowość przyznania także innym synom króla polskiego rocznych pensji na dobrach we Włoszech i przyjęcia na wychowanie na dworze madryckim jednego z młodych Wazów tak, jak to czyniono w stosunku do członków linii wiedeńskiej Domu Austrii. Plany i propozycje nie zostały zrealizowane, ponieważ Hiszpania z powodu wybuchu wojny w północnych Włoszech musiała porzucić dotychczasowe działania w strefie bałtyckiej.

Bliskie relacje łączące Władysława IV z Filipem IV stały się podstawą jego starań o pomoc finansową i urzędy dla młodszych braci na dworze madryckim ${ }^{69}$. Zabiegi o uposażenie dla rodzeństwa król zintensyfikował po 1635 r., kiedy Hiszpania zaczęła aktywnie zabiegać o polską pomoc wojską w wojnie z Francją. Król hiszpański zobowiązywał się wówczas nadać młodym Wazom roczne pensje, m.in. Janowi Kazimierzowi w wysokości 12 tys. dukatów, natomiast biskupowi Karolowi Ferdynandowi jedno z beneficjów w arcybiskupstwie położonym w którymś z państw podległych Hiszpanii. Przez następne kilka lat ambasador polski w Madrycie Stanisław Mąkowski zasypywał Filipa IV i urzędników hiszpańskich listami i memoriałami w sprawie uposażenia dla braci króla, w których żądał zrealizowania obietnic poprzez umieszczenie pensji na jakimś lennie w Neapolu, Flandrii lub Mediolanie, w tym ostatnim przypadku szczególnie wytrwale zabiegał o nadanie Janowi Kazimierzowi burgrabstwa Caravaggio. Dla Karola Ferdynanda wskazywał

${ }^{68}$ Skowron 2002, s. 173-234.

${ }^{69}$ Więcej na temat zabiegów Władysława IV na dworze hiszpańskich Habsburgów w sprawie pensji i uposażenia dla braci zob. Skowron 2013, passim. 
wakujące beneficja w arcybiskupstwach: Toledo, Sevilli, Saragossie, Palermo i innych. Dwór hiszpański, pod licznymi pretekstami, przesuwał terminy realizacji przedstawianych propozycji.

Filip IV, aby jeszcze mocniej związać Wazów z Habsburgami, w połowie 1637 roku zaproponował Janowi Kazimierzowi objęcie urzędu wicekróla Portugalii. Zgodnie z postanowieniami unii kastylijsko-portugalskiej urząd ten mogła pełnić jedynie osoba związana więzami krwi z Domem Austrii, królewicz ten warunek spełniał. Pod koniec stycznia 1638 r. Jan Kazimierz wyruszył do Hiszpanii, ale jego podróż, jak już wyżej wspomniano, zakończyła uwięzieniem na terenie Francji. Podczas trwającej dwa lata niewoli toczyły się intensywne polsko-hiszpańskie rokowania w sprawie sojuszu skierowanego przeciw Francji. Król Władysław IV w ich trakcie jeszcze bardziej zbiegał o hiszpańską pomoc dla rodzeństwa, domagając się od Filipa IV: powołania przyrodniego brata, wówczas już biskupa wrocławskiego, Karola Ferdynanda na arcybiskupa Toledo, nadania Janowi Kazimierzowi, po uwolnieniu z niewoli francuskiej, urzędu wicekróla w jednym z państw monarchii hiszpańskiej, przyznania środków na posag przyrodniej siostrze Annie Katarzynie i pensji dla swojego syna Zygmunta Kazimierza.

Zygmunt III symbolem związków rodzinnych z Habsburgami uczynił Order Złotego Runa ${ }^{70}$. Klęska arcyksięcia Maksymiliana w bitwie z wojskami wiernymi Wazie i uwięzienie arcyksięcia zaskoczyły Filipa II. Porażka ta nadszarpnęła autorytet całego rodu, oznaczała również kres marzeń o koronie polskiej dla Domu Austrii. Zygmunt III, pomimo prohabsburskiej polityki i związków rodzinnych z Wiedniem, nie miał żadnych szans, aby ten król hiszpański uczynił go kawalerem orderu. Uczynił to dopiero jego następca Filip III, który w przeciwieństwie do ojca nie miał żadnych uprzedzeń wobec króla polskiego. W 1601 r. do Polski przybył, z licznym orszakiem, poseł hiszpański Flamandczyk hrabia Lamoral de Ligne i król herbowy Orderu Francois Damant. Ceremonia wręczenia Złotego Runa królowi odbyła się 25 lutego w kolegiacie Św. Jana w Warszawie. Filip III bardzo szybko również zareagował na przedstawioną mu 1614 r. prośbę swojej szwagierki królowej Konstancji o przyznanie Orderu królewiczowi Władysławowi. Wręczenie mu Złotego Runa, które przywiózł specjalny poseł króla hiszpańskiego Jean Hervart, odbyło się w dzień św. Andrzeja 1615 r. w Warszawie. Bardzo zagmatwane są okoliczności nadania i wręczenia Złotego Runa Janowi Kazimierzowi. Obietnicę powołania go na członka Zakonu złożył w 1636 r. przebywający w Polsce poseł hiszpański hrabia de Solre. Filip IV zwlekał jednak z podjęciem ostatecznej decyzji i dopiero w sierpniu 1638 r., kiedy Jan Kazimierz przebywał w niewoli francuskiej, nadał mu Order. Nie znamy jednak okoliczności wręczenia

70 Okoliczności nadania i wręczenia Orderu Złotego Runa Wazom przedstawił Skowron 2009, s. 227-233. 
królewiczowi Złotego Runa. Najprawdopodobniej uczynił to sam król Władysław IV między wrześniem 1640 a majem 1641 roku. Złote Runo przynosiło Wazom wielki splendor, podnosiło ich prestiż i umacniało pozycję wśród panujących dynastii. W sposób bardzo umiejętny i szeroki wykorzystywali oni order w swoich działaniach propagandowych i ideowych. Łańcuch był nie tylko zawieszony na szyi władcy na prawie wszystkich portretach, ale wzorem Habsburgów zaczął okalać herb państwa. Pierwsze szerokie wykorzystanie Orderu jako elementu propagandowo-dekoracyjnego miało miejsce w odnowionym po pożarze zamku królewskim na Wawelu. Władysław IV posunął się jeszcze dalej, podjął bowiem próbę powołania, na wzór burgundzko-hiszpański, zakonu rycerskiego z orderem, ale skutecznie przeciwstawiła się temu szlachta polska.

Na bezpośrednie relacje i związki Wazów z krewnymi zagranicą najsilniej wpływała sytuacja polityczna i religijna. W początkowym okresie swoich rządów w Rzeczypospolitej Zygmunt III pozostawał w luźnych, ale poprawnych kontaktach z krewnymi szwedzkim. Ich wyznanie protestanckie nie miało decydującego wpływu na wzajemne relacje, chociaż pozbawiało ich możliwości pełnienia niektórych funkcji o charakterze religijnym, np. matki czy ojca chrzestnego. Brak współpracy Wazów z krewnymi żyjącymi na terenie Rzeszy, z których część była katolikami, wynikał z ich niskiej pozycji w hierarchii dworów europejskich Detronizacja króla w Szwecji doprowadziła do zerwania wszelkich osobistych więzi między członkami rodu Wazów zasiadającymi na tronach w Sztokholmie i Warszawie. Synowie Zygmunta III, z wyjątkiem królewicza Władysława, nie utrzymywali kontaktów z krewnymi szwedzkimi. Rodzinna Europa Wazów polskich to przede wszystkim Habsburgowie, krewni po kądzieli. To krewni z najbardziej prestiżowych dworów europejskich w Wiedniu, Madrycie, Brukseli, Florencji i Paryżu byli zapraszani na rodziców chrzestnych przychodzących na świat dzieci królów, to ich odwiedzali młodzi królewicze w czasie swoich europejskich podróży, to oni dysponowali pieniędzmi i urzędami o które zabiegali młodzi Wazowie.

\section{BUILDING THE PRESTIGE OF THE ROYAL HOUSE. FAMILIAL RELATIONS OF THE VASA WITH EUROPEAN DYNASTIES}

\section{Summary}

The bonds of kinship became one of the most effective means of raising the prestige and standing for the Vasa dynasty, which sought to occupy an ever higher position in the hierarchy of European rulers. For Zygmunt III, taking wives from the House of Austria were a means through which the Vasa entered the European network of courts, and established channels for cultural exchange and political cooperation. Political and religious circumstances had the greatest impact on direct relations and liaisons of the House of Vasa with the relatives abroad. In the initial period of 
his rule in the Commonwealth, Zygmunt III maintained loose yet thoroughly appropriate contact with the Swedish branch of the family. Their Protestant denomination had no decisive influence on their mutual relationships, though it precluded certain functions of the religious nature, e.g. that of being a godfather or a godmother. Lack of cooperation of the Vasa with the relations living in the Reich - most of whom were Catholic - was due to their low standing in the hierarchy of European courts. The dethronement of the king in Sweden resulted in the severance of all personal bonds between the members of the House of Vasa reigning in Stockholm and Warsaw. The sons of Zygmunt III, with the exception of prince Władysław, never met nor maintained any contact with the Swedish relatives. The European family of the Polish Vasa are chiefly Habsburgs, their distaff relations. Those were the relations from the most prestigious courts of Europe - Vienna, Madrid, Brussels, Florence, and Paris - who were invited to be godparents of the royal children, became hosts to the young princes during their European travels, and had the money and the offices that the young Vasa sought after.

\section{Bibliografia}

\section{Źródła rękopiśmienne}

Archivo General w Simancas: E. 2342.

Archiwum Główne Akt Dawnych: LL 30.

Biblioteka Czatoryskich, Kraków: rkps 107.

Haus-, Hof- und Staatsarchiv w Wiedniu: Familienkorespondenz A, 40 i 41; Polen I 87.

Ratsbücherei w Lüneburgu, Ms. Hist. C 2º 32.

\section{Źródła drukowane}

Aedo y Gallart D. de 1635, El memorable y glorioso viaje del Infante Cardenal D. Fernando de Austria, Amberes.

Falniowska-Gradowska A. 1991, Wjazd, koronacja, wesele Najjaśniejszej Królowej Jej Mości Cecylii Renaty w Warszawie roku 1637, Warszawa.

Grabowski A. 1845, Władysława IV listy i inne pisma, Kraków.

Kobierzycki S. 2005, Historia Władysława, królewicza polskiego i szwedzkiego, wyd. J. Byliński i W. Kaczorowski, Wrocław.

Meysztowicz W, Wyhowska W. 1972, Elementa ad Fontium Editiones, 28: Res Polonicae ex Archivo Mediceo Florentino, III pars, Romae.

Przyboś A. 1977, Podróż królewicza Władysława Wazy do krajów Europy Zachodniej w latach 16241625 w świetle ówczesnych relacji, Kraków.

Radziwiłł A.S. 1980, Pamiętnik o dziejach w Polsce, przekład i oprac. A. Przyboś, R. Żelewski, 1-3, Warszawa.

Skowron R. 2015, Documenta polonica ex Archivo Generali Hispaniae in Simancas.Nova series, I, Cracow.

Skowron R. 2016, The House of Vasa and The House of Austria. Correspondence from the Years 1587 to 1668. I: The Times of Sigismund III, 1587-1632, 1, Katowice.

Sobieski J. 1991, Peregrynacja po Europie [1607-1613] i Doga do Baden [1638], opracował J. Długosza, Wrocław. 


\section{Opracowania}

Augustyniak U. 1999, Wazowie i „królowie rodacy”. Studium władzy królewskiej w Rzeczypospolitej XVII wieku, Warszawa.

Barwicka-Makula A. 2019, Od wrogości do przyjaźni. Habsburgowie austriaccy wobec Polski w latach 1587-1592, Katowice.

Boras Z. 1985, Gustaw Eryksson Waza i jego żywot tułaczy, Poznań.

Brzezińska-Laszczkowa 2008, Karol Ferdynand królewicz polski i biskup wrocławski, Kraków.

Conde Pazos M. 2011, El Tratado de Nápoles: el encierro del príncipe Juan Casimiro y la leva de polacos de Medina de las Torres (1638-1642), Studia historica. Historia Moderna 33, s. 123-139.

Dobner H. 2015, Briefwechsel zwischen Erzherzogin Maria von Innerösterreich und ihrer Tochter Anna, Königin von Polen und Schweden, während ihres Aufenthaltes in Schweden 1593/1594 Historische Analyse und Edition, Masterarbeit [online]. Universität Wien [dostęp: 2019-07-13]. Dostępny w Internecie: <http://othes.univie.ac.at/38905/1/2015-08-10_0800925.pdf>.

Dworzaczek W. 1959, Geneaologia. Tablice, Warszawa.

Dzięgiel W. 1936, Utrata księstw opolskiego i raciborskiego przez Ludwikę Marię w r. 1666, Warszawa. Erbe M. 2000, Die Habsburger (1493-1918). Eine Dynastie im Reich und in Europa, Stuttgart.

Ericson Wolke L. 2011, Jan III Waza. Władca renesansowy, Gdańsk.

González Cuerva R. 2016, The spanish embassy in the Empire. Watchtowr od Poland (1590-1624) [w:] Skowron R. (red.), The House of Vasa and The House of Austria. Correspondence from the Years 1587 to 1668. I: The Times of Sigismund III, 1587-1632, 1, Katowice.

Grabowski A. 1835, Groby królów polskich w kościele katedralnym w Krakowie na zamku. Kraków. Kadzik D. 2017, Utrzymanie królewskiej teściowej. Wizyta Marii Bawarskiej podczas wesela Zygmunta III Wazy z Ann a Habsburg (23 maja-16 czerwca 1592), Kraków.

Keller K. 2012, Erzherzogin Maria von Innerösterreich (1551-1608). Zwischen Habsburg und Wittelsbach, Wien-Köln-Weimar.

Kopczyński M. 2002, Wazowie - dynastia skłócona, Kronika Zamkowa 42, 2002, s. 5-20.

Krasińska-Klaupth E., Kozłowska N., Menhard A. 2010, Polskie Orły, Bawarskie Lwy: na topach wspólnych historycznych śladów, Warszawa.

Kraszewski I. 2007, Dynastia a państwo. Tożsamość i rozbieżność polityki na przykładzie Rzeczypospolitej za panowania Jana Kazimierza, w: Spory o państwo w dobie nowożytnej. Między racją stanu a partykularyzmem, red. Z. Anusik, Łódź, s. 121-132.

Larsson L.O. 2009, Gustaw Waza - ojciec państwa szwedzkiego czy tyran, Warszawa.

Larsson L.O. 2005, Arvet efter Gustav Vasa: berättelsen om fyra kungar och ett rike, Stockholm.

Leitsch W. 2009, Das Leben am Hof König Sigismunds III. von Polen, I-IV, Wien-Kraków.

Lepszy K. 1939, Rzeczpospolita polska w dobie sejmu inkwizycyjnego (1589-1592), Kraków.

Leszczyński J. 1969, Władysław IV a Śląsk w latach 1644-1648, Wrocław.

Libiszowska Z. 1963, Żona dwóch Wazów, Warszawa.

Mosbach A. 1869, Kilka kart z dziejów austriacko-szląsko-polskich mianowicie za Zygmunta III, Rocznik Towarzystwa Przyjaciół Nauk Poznańskiego, 5.

Ochmann-Staniszewska S. 2006, Dynastia Wazów w Polsce, Warszawa.

Ödberg F. 1896, Om prinsessan Cecilia Wasa markgrafvinna af Baden-Rodemachern, Stockholm.

Ossoliński M. 1828, Spotkanie się w Polscze Sygfrydy i Gustawa, dzieci Eryka XIV. Króla Szwedzkiego, Czasopismo Księgozbioru Publicznego imienia Ossolińskich 3-4, s. 50-58, 75-84.

Petersson E. 2015, Karol IX. Król bezlitosny, Oświęcim. 
Rastawiecki E. 1853, Imionnik cudzoziemców Adama Kazanowskiego, Biblioteka Warszawska, 2, 441-479.

Serwański M. 1986, Francja wobec Polski w dobie wojny trzydziestoletniej (1618-1648), Poznań.

Skowron R. 2002, Olivares, Wazowie i Bałtyk. Polska w polityce zagranicznej Hiszpanii w latach 1621-1632, Kraków.

Skowron R. 2009, Order Złotego Runa i jego polscy kawalerowie, [w:] F. Wolański i R. Kołodziej (red.), Rzeczpospolita między okcydentalizmem a orientalizacją. Przestrzeń kontaktów, Toruń, s. 213-232.

Skowron R. 2012, Królewicza Aleksandra Wazy peregrynacja po Italii (1633-1634), [w:] Sic erat in fatis. Studia i szkice historyczne dedykowane Profesorowi Bogdanowi Rokowi, I, Toruń, s. 443451.

Skowron R. 2013, Pax i Mars. Polsko-hiszpańskie relacje polityczne w latach 1632-1648, Kraków.

Skowron R. 2017, Ceremoniał przyjęcia ambasadora hiszpańskiego Francisca de Mendozy na Warszawskim dworze Wazów w roku 1597, Kronika Zamkowa 4 (70), s. 25-46.

Szmydki R. 2002, Kontakty artystyczne królewicza Władysława Zygmunta Wazy z Antwerpią, Warszawa.

Szulc T. 2015, Status prawnomajątkowy Ludwiki Marii de Gonzaga w świetle intercyz małżeńskich, Studia Prawno-Ekonomiczne, 96, s. 145-162.

Szulc T. 2016, Niedynastyczne małżeństwa Jagiellonów i królów elekcyjnych, [w:] Głuszak M., Wiśniewska-Jóźwiak D. (red.), Nil nisi veritas. Księga dedykowana Profesorowi Jackowi Matuszewskiemu, Łódź, s. 243-274.

Targosz-Kretowa K. 1967, Teatr dworski Władysława IV (1635-1648), Kraków.

Tomkiewicz W. 1957, Więzień kardynała. Niewola francuska Jana Kazimierza, Warszawa.

Wasilewski T. 1984, Ostatni Waza na polskim tronie, Katowice.

Wdowiszewski Z. 2005, Genealogia Jagiellonów i Domu Wazów w Polsce, Kraków.

Wolke L. E. 2011, Jan III Waza. Władca Renesansowy, Finna.

Żukowski J. 2015, Listy Władysława Wazy i inne nieznane źródła do jego europejskiej peregrynacji z archiwów szwedzkich i niemieckich, Kronika Zamkowa. Seria Nowa 2, s. 61-85.

Żukowski J. 2017, Infantka Anna Katarzyna Konstancja i kultura artystyczno-kolekcjonerska dworu Wazów, Biuletyn Historii Sztuki 79, 2, s. 233-313. 